Abstracta Iranica Abstracta Iranica

Revue bibliographique pour le domaine irano-aryen

Volume 25 | 2004

Comptes rendus des publications de 2002

\title{
" The Shiraz Hoard Revisited ». SAN Journal of the Society for Ancient Numismatics, XXI, (2002), pp. 30-35.
}

Rika Gyselen

\section{(2) OpenEdition}

Journals

Édition électronique

URL : http://journals.openedition.org/abstractairanica/4171

ISSN : 1961-960X

Éditeur :

CNRS (UMR 7528 Mondes iraniens et indiens), Éditions de I'IFRI

Édition imprimée

Date de publication : 15 mai 2004

ISSN : 0240-8910

Référence électronique

Rika Gyselen, « « The Shiraz Hoard Revisited ». SAN Journal of the Society for Ancient Numismatics, XXI, (2002), pp. 30-35. », Abstracta Iranica [En ligne], Volume 25 | 2004, document 41, mis en ligne le 15 mars 2006, consulté le 25 septembre 2020. URL : http://journals.openedition.org/abstractairanica/ 4171

Ce document a été généré automatiquement le 25 septembre 2020.

Tous droits réservés 


\title{
« The Shiraz Hoard Revisited ». SAN Journal of the Society for Ancient Numismatics, XXI, (2002), pp. 30-35.
}

\author{
Rika Gyselen
}

1 Le "trésor monétaire de Shiraz" est apparu sur le marché numismatique dans les années 60 de manière dispersée. Certaines portions de ce trésor qui a dû comporter des milliers de monnaies ont été publiées avec plus ou moins de précision. La monnaie la plus récente de ce trésor date de l'année 13 de Khusro II. L'A. a pu examiner 347 drachmes qui appartenaient probablement à ce même "trésor de Shiraz" et en propose l'inventaire. On peut toutefois se demander si les monnaies rognées que l'A. mentionne appartiennent réellement à ce trésor.

\section{INDEX}

Thèmes : 3.0. Généralités

\section{AUTEURS}

RIKA GYSELEN

CNRS - Paris 